\title{
Diagnostics of future preschool educators research skills development
}

\author{
E.V. Vezetiu ${ }^{1 *}$, E.V. Vovk $^{2}$, and $O . B$. Martynyuk $^{3}$ \\ ${ }^{1}$ V.I. Vernadsky Crimean Federal University, Simferopol, Russia \\ ${ }^{2}$ V.I. Vernadsky Crimean Federal University, Simferopol, Russia \\ ${ }^{3}$ State Budget Educational Institution of Higher Education of the Republic of Crimea Crimean \\ Engineering and Pedagogical University the name of Fevzi Yakubov, Simferopol, Russia
}

\begin{abstract}
The article deals with the process of diagnostics of future preschool educators' research skills development. The need to develop a system of diagnostics of future preschool educators' research skills development is justified by the need to develop students ' components of research competence specified in the Federal State Educational Standard of Higher Education (FSES HE). The system of activity of the modern teacher of preschool education involves not only implementation of education and training of children, but also organization and conduct of research activities with pupils, elementary preparation of preschoolers for implementation of the analyzed activities in the future which justifies the need for diagnostics of future personnel educators' research skills development in the process of their professional training in high school. The success of analyzed skills of future teachers' development cannot be determined without diagnostic operations to identify the level of specialists' research competence development. Thus, the purpose of this study is to solve the problem of criteria and indicators; determination the levels of research skills and their characteristics development. The aim of the research is realized by applying methods of pedagogical diagnostics, analysis and generalization. Practical and theoretical novelty of the study is justified by the fact that in its course, methods of selection and compilation of diagnostic tools, principles of implemented diagnostic operations and pedagogical conditions for their implementation are determined and a universal algorithm of actions for the use of diagnostic tools is developed. It allows determining the objective level of diagnostics of future preschool educators' research skills development in order to imperfect it by adjusting and improving the whole methodological system. The results of the study allowed justifying the effectiveness of the developed system of pedagogical diagnostics which allows using it in future in determining diagnostics of future preschool educators' research skills development.
\end{abstract}

\section{A problem statement}

In the system of vocational education of future preschool teachers, one of the most important content lines of training is research skills development [16].

* Corresponding author: ipcs-profped@yandex.ru 
In the framework of this study, "the teacher's research skills" is understood as the personality trait that characterizes his ability to search and transform activities in the educational process [5]; the ability of individuals to acquire new knowledge and skills that contribute to professional development and self-development [3].

The need to develop a special methodological system for diagnostics of future preschool educators' research skills development, in our opinion [1], is justified by the possibility of resolving contradictions between the requirements of teaching and research activities and the existing level of students' readiness for independent research activities; between the potential possibilities of creative training of specialists in higher pedagogical institutions and their insufficient implementation; between the need to improve the level of readiness for educational research activities of future educators and the lack of a scientifically based system for their training [17].

The use of the above methodical system and verification of its effectiveness as a degree of consistency between the achieved and projected results requires diagnostic studies of the level of research skills of future educators of preschool institutions development at all stages of its implementation [19]. Based on this, it is necessary to develop diagnostic tools, as well as the selection of objective criteria and indicators for determining the level of the skills development.

In this article, we will reveal the essence of diagnostic operations to determine the level of skills development that can be used in higher educational institutions in the implementation of professional training of future teachers of preschool education [2].

\subsection{The objective of the work}

Diagnostics is one of the most important components of any pedagogical activity, an integral part of the didactic process, a way of analyzing the educational process and determining its effectiveness with the aim of improvement.

Pedagogical diagnostic activity is a process in which, when the necessary scientific criteria are met, a teacher observes students, conducts surveys, processes observational data and surveys, and reports results to describe behavior, explain its motives, or predict future behavior [20].

According to O.Yu. Efremova, pedagogical diagnostics in high school as a subsystem of the pedagogical system of the university and higher education in general reflects its structure and can be considered as an independent pedagogical system with five structural components:

- the purpose of diagnosis;

- content of the diagnosed information;

- the object of diagnosis (diagnosed);

- diagnostic tools [18];

- diagnostician (subject of diagnosis) [14].

The effectiveness of future preschool educators' research skills development largely depends on the definition of the level characteristics. In this context, the level will be understood as the degree, magnitude of development of a certain phenomenon, the fact of its differentiation into groups [10]. The level of development of this or that personal education in pedagogy is determined by certain criteria as a conditional measure which allows one to realize the phenomenon and on this basis give it an assessment [8].

In domestic pedagogy, the problem of determining criteria and indicators in pedagogical research is reflected in the works of such teachers as Yu.K. Babansky A.V. Drummers, N.A. Selezneva, N.V. Kuzmina and others. Based on the analysis of theoretical developments of these authors, the criterion is understood by us as:

- indicator, objective manifestation of something [10];

- psychological installation diagnostician; 
- measure of the implementation of diagnosis;

- question of the questionnaire, test, task [15].

"Speaking in the role of the standard, the norm, the criterion serves as an ideal model, expresses the highest [11], most perfect level of the phenomenon being studied [13]. Comparing with it real phenomena, it is possible to establish the degree of their conformity, approximation to the norm and ideal" [21].

Thus, the criterion is the optimal model for comparison with real phenomena [12]. With the help of these criteria it is possible to establish a measure of conformity to the approximation of the actual level of formation of a pedagogical phenomenon to a given model [9]. The criteria make it possible to determine how a certain pedagogical result can be achieved, in this case, to form the necessary level of future preschool educators' research skills development [6].

A.K. Markov distinguishes such groups of criteria as:

- objective and subjective;

- effective and procedural;

- normative and individually variable;

- real and prognostic level;

- vocational education and creativity;

- social activity and professional fitness;

- qualitative and quantitative [17].

A certain level or state of development of the criterion is fixed [18]. It particular, there is manifestation of one of the essential aspects of a certain personality quality. E.A. Semenov as an indicator understands phenomena or events by which one can judge the dynamics of a certain process. The use of indicators helps to assess the quality and future preschool educators' research skills development.

According to Z.A. Mendubayeva, "the main characteristics of an "indicator "are concreteness, which is the gauge of the latter, and diagnostics which allows the indicator to be available for observation and recording.

Diagnostics of the level of future preschool educators' research skills development was implemented as part of an experiment to introduce and test a methodological system for the formation of these professional skills of educators. The study was based on the Humanitarian Pedagogical Academy (branch) of FSAE "Crimean Federal University named after V.I. Vernadsky "in Yalta. The respondents of the experiment were students of the 4th year of the Academy of the specialty "Pedagogical education" (profile "Pre-school education"). As part of the experiment, a primary (before the introduction of the methodical system) and control diagnostics (after the introduction of the methodical system) was carried out. Of the study participants were formed experimental (EG: 26 people) and control groups (CG: 23 people). The chronological framework of the primary diagnosis (taking into account long-term research methods) covered 1 semester, and the control one one third of the second semester of the 2017-2018 school year.

\section{Materials and the results of the research}

Having considered theoretical aspects of pedagogical diagnostics, let us turn to characteristics of the process of experimental diagnostics of the level of future preschool educators' research skills development.

Diagnostics of the level of future preschool educators' research skills development was implemented as part of an experiment to introduce and test a methodological system for specified professional skills of educators development. The study was based on the Humanitarian Pedagogical Academy (branch) of FSAE "Crimean Federal University named after V.I. Vernadsky "in Yalta. The respondents of the experiment were students of 
the 4th year of the Academy whose major is "Pedagogical education" (profile "Pre-school education"). As part of the experiment, a primary (before the introduction of the methodical system) and control diagnostics (after the introduction of the methodical system) was carried out. We formed experimental (EG: 26 people) and control groups (CG: 23 people). The chronological framework of the primary diagnosis (taking into account long-term research methods) covered 1 semester, and the control one - one third of the second semester of the 2017-2018 school year.

Successful implementation of the pedagogical diagnostics of the research skills of preschool education teachers involved the creation of the following pedagogical conditions:

- effective organization of pedagogical diagnostics including technologies and qualimetric methods, measurement;

- optimal selection of relevant ways to implement research objectives;

- targeted training of specialists for the implementation of pedagogical diagnostics.

Diagnostics of the level of future preschool educators' research skills development was implemented with the following didactic principles of diagnosis and control:

- objectivity;

- systematic;

- comprehensive coverage.

The essence of the principle of objectivity in this study lies in the scientific substantiation of the content of diagnostic tests and tasks, a range of diagnostic procedures; consecutive stages of diagnostics; an unbiased attitude of specialists implementing diagnostics to each participant in the experiment; using a scientific approach to assessing phenomena and formulating conclusions.

The principle of systematicity is the need for regular diagnostic testing at all stages of the experiment.

The principle of comprehensive coverage provides necessary completeness of monitoring and evaluation, focusing on the need to fully cover all aspects of the phenomenon being studied.

To build the criterion apparatus of pedagogical diagnostics, we chose the way to use criteria based on the structure of the components of teachers' readiness to implement research activitie, namely: motivational-value, informational, operational-activity, reflexive. The interdependence of the chosen criteria and their indicators is shown in table 1.

Table 1. Criteria and indicators of future preschool educators' research skills development.

\begin{tabular}{|c|c|c|c|}
\hline \multicolumn{4}{|c|}{ Criteria } \\
\hline $\begin{array}{c}\text { Motivational and } \\
\text { value }\end{array}$ & Cognitive-procedural & $\begin{array}{l}\text { Operational } \\
\text { activity }\end{array}$ & Reflective \\
\hline \multicolumn{4}{|c|}{ Indicators } \\
\hline $\begin{array}{l}\text { interest in research } \\
\text { activities }\end{array}$ & $\begin{array}{l}\text { interest in research } \\
\text { activities }\end{array}$ & $\begin{array}{l}\text { Proficiency in } \\
\text { research methods }\end{array}$ & $\begin{array}{l}\text { ability to self- } \\
\text { analyze and } \\
\text { reflection }\end{array}$ \\
\hline $\begin{array}{l}\text { developed personal } \\
\text { motivation }\end{array}$ & $\begin{array}{l}\text { knowledge and } \\
\text { determination of ways to } \\
\text { achieve the goal of } \\
\text { research activities }\end{array}$ & $\begin{array}{l}\text { independent } \\
\text { management and } \\
\text { monitoring of } \\
\text { research results }\end{array}$ & $\begin{array}{l}\text { the ability to } \\
\text { observe }\end{array}$ \\
\hline personality research & & & $\begin{array}{l}\text { development of } \\
\text { the ability to } \\
\text { reason, to reflect } \\
\text { on their actions }\end{array}$ \\
\hline $\begin{array}{l}\text { the need for the } \\
\text { implementation of } \\
\text { research activities }\end{array}$ & & & \\
\hline
\end{tabular}


On the basis of taking into account the proposed criteria and indicators, we identified three levels of formation developed, sufficient, elementary. We turn to the consideration of these levels.

Students with a developed level are capable of independent analysis of problematic issues, are free to use scientific terminology, systematically carry out information retrieval on the Internet and use pedagogical software when planning and conducting classes. As part of teaching practice, future educators at the proper level carry out diagnostics and selfdiagnostics, conduct classes and educational activities with the use of elements of innovative educational technologies. Such students have a tendency to self-knowledge, selfesteem and implementation of experimental work.

Students with a sufficient level are characterized by a weak manifestation of creative possibilities. They occasionally carry out information search on the Internet and rarely use additional sources of information independently. Such students can carry out diagnostics and self-diagnostics only with the help of a teacher. They mainly use traditional methods of teaching and education in practice.

Students of the Academy with an elementary level are characterized by limited selfreporting of the material, they do not sufficiently assimilate basic scientific terms and concepts, do not know how to delineate a specific subject of diagnostics and develop research tools. They tend to lack self-diagnosis skills, reflection and correction of their own activities. Within the framework of the practice, such students carry out educational activities according to traditional programs and methods, use a random set of methods and show indifference to research work.

The identification of the levels of future preschool educators' research skills development and motivation for research activities among students was realized through the use of methods such as observing students in lectures, seminars, testing, questioning, conversations with teachers and students. The basis of diagnostic tools was the "Bloom 1956 Taxonomy of Pedagogical Objectives". The definition of the qualitative characteristics of future preschool educators' research skills development was reduced to the definition of designated levels.

The developed diagnostic methodology based on theoretical concepts of pedagogical diagnostics (Yu.K. Babansky, B. Blum, O.Yu. Efremova, N.V. Kuzmina, E.A. Semenova) and methodological development of future preschool educators' research skills development (structure components of teachers 'readiness to implement research activities (Mendubaeva); diagnostic tools for studying the level of development of research skills and skills of future AEO leaders (T.L. Chumakhidze, LK Mambetova), allowed to determine the levels of development of research skills of future educators preschool. The results of the primary diagnosis are presented in figure 1.

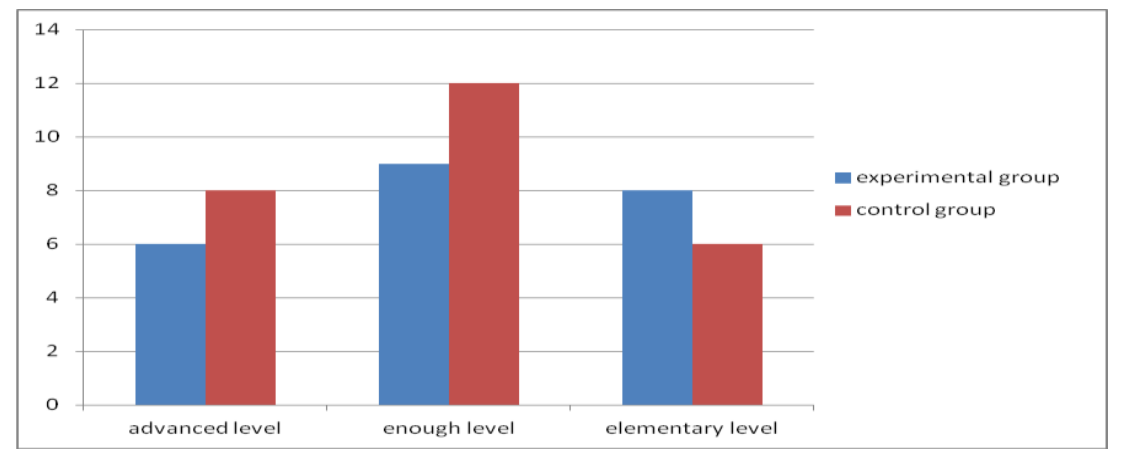

Fig. 1. The results of the primary diagnosis of future preschool educators' research skills development (as part of our study). 


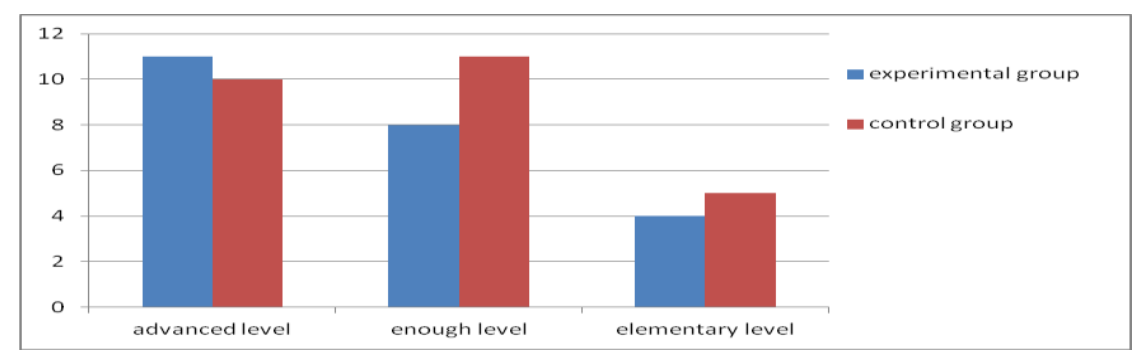

Fig. 2. Results of primary diagnostics of future preschool educators' research skills development (as part of our study).

\section{Conclusions}

The developed diagnostic methodology based on theoretical concepts of pedagogical diagnostics (Yu.K. Babansky, B. Blum, O.Yu. Efremova, N.V. Kuzmina, E.A. Semenova) and methodological development of future preschool educators' research skills development (structure components of teachers 'readiness to implement research activities; diagnostic tools for studying the level of development of research skills and skills of future AEO leaders (T.L. Chumakhidze, L.K. Mambetova), allowed to determine the levels of development of research skills of future educators preschool.

Future preschool educators' research skills development in education system is one of the most important tasks for the implementation of professional future preschool educators' research skills, in our opinion, will be meaningless without timely and systematic verification of its effectiveness. For this purpose, a prerequisite is an appeal to the methods of pedagogical diagnostics, which allow determining the level of research skills development and evaluation of implemented methodological system effectiveness.

\section{References}

1. L.V. Aleksieienko-Lemovska, The activity approach as a basis for preschool teachers' methodological activities, Humanitarian Balkan Research, 3, 4 (6), 10-14 (2019)

2. T.K. Andriushchenko, Personal aspects of pedagogue's innovative culture, Scientific Vector of the Balkans, 1, 13-16 (2018)

3. N.P. Bakharev, Creativity - a prerequisite for the formation of professional competences in specialists of technical direction of training, Scientific Vector of the Balkans, 3, 4 (6), 17-21 (2019)

4. M.N. Bulayeva, Ye.A. Aleshugina, K.A. Maksimova, Modeling of the process of formation competence of teachers in university, Baltic Humanitarian Journal, 8, 3 (28), 21-24, in Russ (2019)

5. O.YU. Donetskova, Modernization of the modern education system in Russia, Baltic Humanitarian Journal, 8, 2 (27), 37-39, in Russ (2019)

6. I.F. Filchenkova, Educational management of innovative activity of teachers as an object of pedagogical research, Vestnik of Minin University 7 (4), 3, in Russ (2019).

7. S.G. Grigoriev, V.A. Shabunina, Ju.M. Tsarapkina, N.V. Dunaeva, Electronic library system as a means of self-development of students of digital generation $Z$ (on the example of studying the course "Basics of the counselor activity"), Scientific and technical libraries, 7, 78-99 (2019) 
8. E.V. Myalkina, Diagnostics of the education quality in the higher educational institution, Vestnik of Minin University, 7 (3), 4, in Russ (2019)

9. I.I. Oros, The role of international connections in the development of the adult education system, Humanitarian Balkan Research, 1, 57-59 (2018)

10. I.I. Osadchenko, Key concepts of situational training technology in preparing future teachers, Scientific Vector of the Balkans, 1 (3), 46-49 (2019)

11. G.A. Pichugina, A.I. Bondarchuk, Structure of the training case in the organization of the educational process, Humanitarian Balkan Research, 2 (4), 5-7 (2019)

12. G.A. Pichugina, D.A. Zhilyakova, Structuring the organization of the process of creativity, Scientific Vector of the Balkans, 3, 3 (5), 55-58 (2019)

13. D.A. Pisarenko, Evaluation of extracurricular activities of university students with a competency-based approach, Scientific Vector of the Balkans, 3, 3 (5), 37-40 (2019)

14. V.M. Pliushch, Independent work of students as a factor of improving education quality, Balkan Scientific Review, 1, 69-71 (2018).

15. J. Raven, Education and Sociocybernetics, Azimuth of Scientific Researches: Economics and Management, 6, 3 (20), 289-297 (2017)

16. Z.A. Tolkanuk, Professional self-determination of youth as a factor of training of a competent specialist, Balkan Scientific Review, 3, 2 (4), 57-59 (2019)

17. Ju.M. Tsarapkina, M.M. Petrova, A.G. Mironov, I.M. Morozova, O.B. Shustova, Robotics as a basis for Informatization of education in children's health camp, Amazonia Investiga, 8 (20) (2019)

18. Ju.M. Tsarapkina, N.V. Dunaeva, A.M. Kireicheva, Application of BYOD technology in education on the example of Lecture Racing mobile application, Informatics and Education, 9 (308), 56-64 (2019)

19. O.I. Vaganova, L.I. Ilyashenko, Zh.V. Smirnova, N.V. Bystrova, S.N. Kaznacheeva, Students' creative abilities development in higher educational institution, Amazonia Investiga, 8 (22), 701-710 (2019)

20. O.I. Vaganova, I.V. Rudenko, S.M. Markova, Zh.V. Smirnova, M.M. Kutepov, The use of educational video materials in educational process of a higher educational institution, Amazonia Investiga, 8 (22), 216-222 (2019)

21. O.I. Vaganova, Yu.A. Livshits, E.A. Aleshugina, Zh.V. Smirnova, L.I. Kutepova, Experience in developing electronic glossary in a higher education institution, Amazonia Investiga, 8 (22), 247-253 (2019) 